DOI: 10.20472/EFC.2018.010.031

\author{
ROMA RYŚ-JUREK \\ Poznań University of Life Sciences, Poland
}

\title{
DETERMINANTS OF FAMILY FARM INCOME: FINDINGS FROM THE PANEL DATA ON THE TYPE OF PRODUCTION IN THE EU COUNTRIES
}

\begin{abstract}
:
The aim of this research is to present the family farm income and its determinants according to the type of production of farms in the EU countries in 2004-2016. Research is based on European Farm Accountancy Data Network (FADN), which includes information about average farms in the EU-28. These data include basic information about economic situation of 2335 production types according to the TF8 grouping, i.e.: fieldcrops, horticulture, wine, other permanent crops, milk, other grazing livestock, granivores and mixed.

In this paper an attempt is made to use the panel models to evaluate the determinants of family farm income. The Gretl program is used to evaluate fixed effect models and random effect models allowing to indicate determinants of family farm income depending on the farm's type of production.
\end{abstract}

\section{Keywords:}

FADN, family farm income, panel data

JEL Classification: C23, Q12, Q14 


\section{Introduction}

Family farming includes all family-based agricultural activities. It is linked to several areas of rural development as it organizes agricultural, forestry, fisheries, pastoral and aquaculture production which is managed and operated by a family and predominantly reliant on family labour. Both in developing and advanced economies, family farming is the predominant form of agriculture in the food production sector (FAO, 2014). Family farms are by far the most common type of farm in the European Union (EU). There is a wide range of agricultural holdings starting from small, semi-subsistence farms with only family workers and farms, which have to rely on other activities in order to diversify sources of income ${ }^{1}$, ending with larger farms that also pursue family management (EUROSTAT 2016).

The support of family income of these farms (by direct payments) remains an essential part of the Common Agricultural Policy (CAP) in line with EU Treaty obligations (The Future of Food... 2017). It should be emphasized that the long tradition of widespread support for farms is unique in agriculture as compared to other sectors (Frawley et al. 2000). Incomes of farm households is traditionally seen as primus inter pares among other targets of agricultural policy, but in recent years objectives related to the environment, sustainability, rural development and food safety have also become important. Despite changing importance of the objectives, support to agriculture is still dominated by price support, output and input subsidies or area payments. However, very often these activities are not well-structured or organized. Therefore, it is often difficult to associate a policy tool with a specific objective, and particularly, to identify the policies responsible for addressing income problems (OECD 2003).

Taking into account abovementioned considerations, as well as the primary aim of CAP to support incomes in agriculture, the purpose of the paper is to examine the determinants of family farm income. Undertaken research allows for a deeper understanding of dependence among the type of farm's production and various economic factors.

Two hypothesis of research are formulated:

- determinants affecting income vary depending on the type of production of the farm,

- significance of work, land, and capital as factors of production is different in each type of agricultural production.

${ }^{1}$ Farm family income is after the further deduction of the costs of hired labour, interest paid and rent paid and is the return to the farmer for the use of his own labour, own land and own capital; it represents the amount generated by the farm business that is available for consumption, investment and saving (Comparison of farmers' incomes... 2015). 
The paper is organized follows. The next section reviews the literature on the family farming and incomes in agriculture. Section 3 describes the data used and method of panel data analysis. Section 4 presents the results of the analysis. Section 5 concludes.

\section{Theoretical backgrounds}

Economists and specialists generally agree that investing in agriculture is an effective strategy for reducing poverty, inequality and hunger, especially in countries, where this sector employs a large share of the population. However, there is an ongoing debate regarding type and scale of agriculture to be promoted in order to achieve these goals most effectively (Lowder et al. 2016)2.

Growth in farmers' incomes is fundamental to economic and social development and to farmers' ability to reinvest in their farms (Enabling smallholder... 2017). According to the household socio-economic point of view, the aim of the household is to maximize income from crop and livestock activities under certain circumstances (Nibbering and van Rheenen 1998), as well as the farms' income. Farmers are continuously making decisions concerning the allocation of their resources of land, labour, capital and entrepreneurial ability. Their behaviour is motivated by the attempt to maximize levels of satisfaction or utility.

Most studies that analyse farmer decision-making process, however, assume the single objective of profit maximisation as the sole motivation for farmers' behaviour. Therefore, farmer is interested primarily in increasing gross margin, reducing indebtedness, avoiding risk, expanding the business, improving family living standard, achieving sufficient leisure time, etc., but not necessarily in this order (Wallace and Moss 2002). Making a satisfactory income and safeguarding its future levels are the mains goals of farmers (Berbel and Rodriguez-Ocaña 1998; Cary and Holmes 1982; Gasson 1973; Solano et al. 2001).

Is should be underlined that the increasing pressure on land and the growing demand for livestock products makes it more and more important to ensure the effective use of feed resources, including crop residues (IFAD 2010). Therefore, the significance of type of production, understood as a combination of crop and livestock production, for achievement of farmers' goals is analysed by researches (for example: Asai et al. 2018, Beck and Dent 1987, Ibrahim and Omotesho 2011, Okoruwa et al. 1996, Rosato and Stellin 1995). In this study, the impact of type of production on family farm net income is

\footnotetext{
2 Family farming has an important socio-economic, environmental and cultural role. At national level, there are a number of factors that are key for a successful development of family farming, such as: agro-ecological conditions and territorial characteristics; policy environment; access to markets; access to land and natural resources; access to technology and extension services; access to finance; demographic, economic and socio-cultural conditions; availability of specialized education among others (FAO, 2014). Farming is a risky business because forces beyond the control of farmers, such as weather, affect their income. Therefore, farm income stability has been one of the goals of agricultural policies both in the US and the EU (Severini et al. 2016).
} 
examined, as well as the relations among land, labour and capital in farms and their income according to the type of production.

\section{Data and methods}

Research is based on the data obtained from Farm Accountancy Data Network (FADN). In this database only the professional farms are included ${ }^{3}$. The FADN has developed a detailed methodology for calculating the family farm income (Fig. 1). The FADN data enable a detailed presentation and analysis of determinants of the family farm income (FADN 2018).

These data include basic information about economic situation of 2335 production types according to the TF8 grouping in the EU in 2004-2016 (Tab. 1). Specialisation of production is determined on the basis of the contributions of the different lines of production to the total standard output 4 .

\section{Figure 1. Family farm net income - calculation according to the FADN methodology}

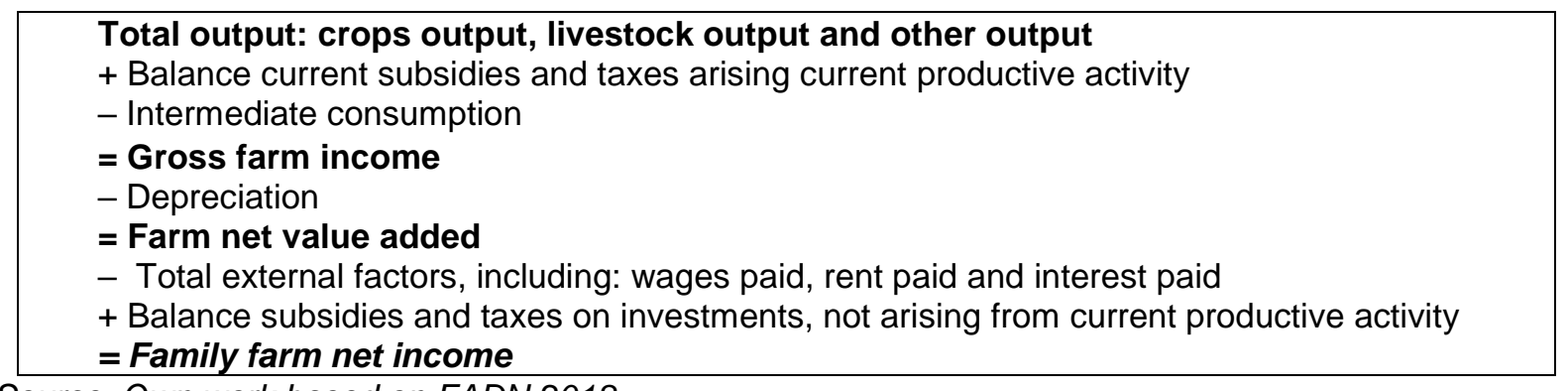

Source: Own work based on FADN 2018.

A particular production type of farm is an aggregate unit, so FADN data has a character of the panel data ${ }^{5}$. A panel data (or longitudinal data) set consists of a time series for

\footnotetext{
3 The FADN is the only source of harmonised farm data which allows EU-wide comparisons. FADN collects and analyses annual data from around 80000 farms. Its main role is to measure European farm incomes and provide business analyses. These farms represent around 5 million farms which cover over $90 \%$ of EU agricultural land and production. Farmers' participation in the FADN is voluntary. The European Commission verifies and processes the data collected in order to prepare analyses and publish relevant statistics. The availability of reliable data at farm level throughout the EU is essential in providing policy-makers with a solid basis on which decisions are undertaken. Also, analyses based on the FADN are useful for stakeholders (be they professional organisations or individual farmers) wishing to compare their situation with that of others (European Commission 2014b).

4 To determine the total standard output calculated values of standard outputs established at the level of the different regions of the EU for the different lines of productions are taken as a basis: e.g. standard output for one hectare of wheat or for one dairy cow. For each holding the number of hectares of wheat or dairy cows is multiplied by the corresponding standard output and by summing them total standard output is calculated. The standard output data are calculated at regular intervals and correspond to five-year averages (European Commission 2014a). Now, a whole database consists of 28 countries (FADN 2018).

${ }^{5}$ Panel data models allow us to construct and test more complicated behavioural models than purely cross-section or time-series data (Baltagi 2005).
} 
each cross-sectional member in the data set over a time period. Panel data can also be collected on geographical units (Wooldridge 2013).

\section{Table 1. Types of production - classification TF8 according to the FADN methodology}

\begin{tabular}{|c|c|c|c|}
\hline No. & Name & Principes types of farming & $\begin{array}{l}\text { Number of observations } \\
\text { in years 2004-2016 }\end{array}$ \\
\hline 1 & Fieldcrops & $\begin{array}{l}\text { - Specialist cereals, oilseeds and protein crops } \\
\text { - General field cropping } \\
\text { - Mixed cropping }\end{array}$ & 343 \\
\hline 2 & Horticulture & $\begin{array}{l}\text { - Specialist horticulture indoor } \\
\text { - Specialist horticulture outdoor } \\
\text { - Other horticulture }\end{array}$ & 267 \\
\hline 3 & Wine & - Specialist vineyards & 177 \\
\hline 4 & $\begin{array}{l}\text { Other permanent } \\
\text { crops }\end{array}$ & $\begin{array}{l}\text { - Specialist fruit and citrus fruit } \\
\text { - Specialist olives } \\
\text { - Various permanent crops combined }\end{array}$ & 251 \\
\hline 5 & Milk & - Specialist dairying & 327 \\
\hline 6 & $\begin{array}{l}\text { Other grazing } \\
\text { livestock }\end{array}$ & $\begin{array}{l}\text { - Specialist cattle - rearing and fattening } \\
\text { - Cattle - dairying, rearing and fattening } \\
\text { combined } \\
\text { - Sheep, goats and other grazing livestock }\end{array}$ & 346 \\
\hline 7 & Granivores & $\begin{array}{l}\text { - Specialist pigs } \\
\text { - Specialist poultry } \\
\text { - Various granivores combined }\end{array}$ & 284 \\
\hline 8 & Mixed & $\begin{array}{l}\text { - Mixed livestock, mainly grazing livestock } \\
\text { - Mixed livestock, mainly granivores } \\
\text { - Field crops - grazing livestock combined } \\
\text { - Various crops and livestock combined }\end{array}$ & 340 \\
\hline
\end{tabular}

Source: Own work based on European Commission 2014a and FADN 2018.

The most general formulation of a panel data model may be expressed as the following equation (see: Baltagi 2005):

$$
y_{i, t}=\alpha_{i}+X_{i, t}^{\prime} \beta+u_{i, t}+\varepsilon_{i, t}
$$

with $i(i=1, \ldots, M)$ denoting individuals, $t(t=1, \ldots, T)$ denoting time periods, and $X_{i, t}^{\prime}$ denoting the observation of $K$ explanatory variables in country $i$ and time $t$.

It should be noted that $\alpha_{i}$ is time invariant and accounts for any individual-specific effect not included in the regression equation. Two different interpretations may be given to the $\alpha_{i}$, and, consequently, two different basic models may be distinguished. If the $\alpha_{i}$ 's are assumed to be fixed parameters to be estimated the model expressed in the equation (1) is Fixed Effect Panel Data Model (FEM). Conversely, if the $\alpha_{i}$ 's are assumed to be random, the Random Effect Panel Data Model (REM) is generated (Arbia and Piras 2005). Fixed Effect Model is particularly suitable when the regression analysis is limited to a precise set of individuals, firms or regions; random effect, instead, is an appropriate 
specification if a certain number of individuals randomly from a large population of reference are drawn (Arbia and Piras 2005) ${ }^{6}$.

In order to choose between Random and Fixed Effect Model, the Hausman test is used ${ }^{7}$. The null and alternative hypotheses of Hausman test are (Adkins 2014):

$$
H_{0}: \operatorname{Cov}\left(x_{i} ; e_{i}\right)=0 \text {, against } H_{a}: \operatorname{Cov}\left(x_{i} ; e_{i}\right) \neq 0 \text {. }
$$

Also, the Variance Inflation Factors (VIF) is used to measure how much the variance of the estimated coefficients is increased over the case of no correlation among the independent variables. If VIF $=0$ there is no multicollinearity (Ergün and Göksu 2013). If the value of VIF test of variable exceeds 10.0, it is the evidence of a collinearity problem (Adkins 2014).

The main target of research is to obtain the model that characterizes determinants of the family farm income according to the type of production. In order to estimate the model, a set of variables - presented in Table 2 - is used.

\section{Table 2. The potential variables used in panel models}

\begin{tabular}{|c|c|}
\hline Variable name & Variable characteristic [measurement units] \\
\hline Y Family farm income & $\begin{array}{l}\text { Remuneration to fixed factors of production of the farm (work, land and capital) and } \\
\text { remuneration to the entrepreneurs risks (loss/profit) in the accounting year [in EUR thous.]. }\end{array}$ \\
\hline X01 Labour input & Is expressed in annual work unit (full-time person equivalent) [in AWU]. \\
\hline $\begin{array}{l}\text { X02 Utilised } \\
\text { agricultural area }\end{array}$ & It consists of land in owner occupation, rented land and land in share-cropping [in hectares]. \\
\hline X03 Total assets & Fixed assets + current assets [in EUR thous.]. \\
\hline X04 Fixed assets & $\begin{array}{l}\text { Agricultural land and farm buildings and forest capital + buildings + machinery and equipment } \\
+ \text { breeding livestock [in EUR thous.]. }\end{array}$ \\
\hline X05 Current assets & $\begin{array}{l}\text { Non-breeding livestock }+ \text { stocks of agricultural products }+ \text { other circulating capital [in EUR } \\
\text { thous.]. }\end{array}$ \\
\hline X06 Economic size & European Size Units (ESU), in values of the Standard Output [in EUR thous.]. \\
\hline X07 Crop output & Output of crops and crops products [in EUR thous.]. \\
\hline X08 Livestock output & Livestock production + change in livestock value + animal products [in EUR thous.]. \\
\hline X09 Taxes & $\begin{array}{l}\text { Farm taxes and other dues (not including VAT and the personal taxes of the holder) and } \\
\text { taxes and other charges on land and buildings [in EUR thous.]. }\end{array}$ \\
\hline X10 Inputs & Specific costs + overheads + depreciation + external factors [in EUR thous.]. \\
\hline X11 Subsidies & Subsidies on current operations + subsidies on investments [in EUR thous.]. \\
\hline X12 Liabilities & Long- , medium- or short-term loans still to be repaid [in EUR thous.]. \\
\hline X13 Equity & Total assets without the liabilities [in EUR thous.]. \\
\hline X14 Gross investment & Purchases - sales of fixed assets + breeding livestock change of valuation [in EUR thous.]. \\
\hline X15 Net investment & Gross investment without the depreciation [in EUR thous.]. \\
\hline X16 Cash flow & $\begin{array}{l}\text { Receipts - expenditure for the accounting year, not taking into account operations on capital } \\
\text { and on debts and loans [in EUR thous.]. }\end{array}$ \\
\hline
\end{tabular}

\section{Source: Own work based on FADN 2018.}

${ }^{6}$ There are several arguments for using random effects models instead fixed effects models (see: Maddala 1987).

${ }^{7}$ The idea is that one uses the random effects estimates unless the Hausman test rejects. In practice, a failure to reject means either that the RE and FE estimates are sufficiently close so that it does not matter which one is used, or the sampling variation is so large in the FE estimates that it is impossible to find practically significant differences which are statistically significant (Wooldridge 2013). 


\section{Results and discussion}

The first stage of empirical research is to present a family farm net income and chosen economic characteristics according to the type of production of farms in 2004 and 2016 (Tab. 3). In 2016, the average family farm net income in the EU-28 was equal to 18,000 EUR from 34 hectares, 72,000 EUR was the average output and the value of assets was 342,000 EUR. In the same time, the average liabilities of farm was equal to 55,000 EUR and total obtained subsidies achieved 12,000 EUR. As compared to 2004, the pace of growth of output and assets achieved c.a. $20 \%$ and in case of liabilities - c.a. $30 \%$. The subsidies increased only by $10 \%$ and income - by $2 \%$. Meanwhile, area and the labour input slightly decreased. The values of income and other economic indicators were different according to the type of production. For example, in 2016 the highest values of income, labour and output was observed in horticulture and granivores farms. The largest area was utilised by fieldcrops and other grazing livestock farms. The other permanent crops and mixed farms were the least equipped in assets. The liabilities were most important in granivores farm, and the highest values of subsidies were obtained by fieldcrops, milk, other grazing livestock and granivores farms (Tab. 3).

Table 3. Family farm net income and chosen economic characteristics according to the type of production of farms in 2004 and 2016

\begin{tabular}{|c|c|c|c|c|c|c|c|}
\hline \multirow{2}{*}{$\begin{array}{l}\text { Year_Typ of } \\
\text { production }\end{array}$} & $\begin{array}{l}\text { Family Farm } \\
\text { Net Income }\end{array}$ & Labour input & $\begin{array}{l}\text { Utilised Agri- } \\
\text { cultural Area }\end{array}$ & Assets & Output & Liabilities & $\begin{array}{c}\text { All } \\
\text { subsidies }\end{array}$ \\
\hline & [EUR thous.] & [AWU] & [ha] & $\begin{array}{l}\text { [EUR } \\
\text { thous.] }\end{array}$ & $\begin{array}{l}\text { [EUR } \\
\text { thous.] }\end{array}$ & $\begin{array}{c}\text { [in EUR } \\
\text { thous.] }\end{array}$ & $\begin{array}{c}\text { [EUR } \\
\text { thous.] }\end{array}$ \\
\hline $2004 \_1$ & 16.44 & 1.46 & 48.16 & 287.76 & 51.91 & 37.05 & 14.57 \\
\hline 2004_2 & 33.00 & 3.25 & 5.82 & 274.14 & 146.27 & 81.61 & 1.95 \\
\hline 2004_3 & 23.46 & 1.72 & 13.51 & 287.49 & 66.71 & 37.78 & 3.05 \\
\hline $2004 \_4$ & 12.48 & 1.26 & 9.19 & 145.14 & 23.84 & 4.70 & 3.42 \\
\hline 2004_5 & 24.62 & 1.85 & 41.98 & 449.34 & 89.40 & 81.52 & 13.97 \\
\hline $2004-6$ & 19.67 & 1.46 & 59.25 & 345.62 & 47.96 & 35.25 & 20.61 \\
\hline 2004_7 & 31.77 & 1.95 & 30.41 & 418.59 & 178.81 & 128.71 & 10.43 \\
\hline 2004_8 & 10.64 & 1.83 & 36.64 & 188.50 & 45.55 & 30.98 & 9.81 \\
\hline 2004_EU average & 17.94 & 1.66 & 35.08 & 276.86 & 60.63 & 41.59 & 11.01 \\
\hline $2016 \_1$ & 15.29 & 1.37 & 50.09 & 372.34 & 62.99 & 53.37 & 14.57 \\
\hline 2016_2 & 45.37 & 3.70 & 6.19 & 367.60 & 191.26 & 93.45 & 3.29 \\
\hline 2016_3 & 34.54 & 1.67 & 14.41 & 405.77 & 93.44 & 49.97 & 4.29 \\
\hline $2016 \_4$ & 18.93 & 1.42 & 12.44 & 249.38 & 43.12 & 13.32 & 5.89 \\
\hline 2016_5 & 20.03 & 1.60 & 33.30 & 442.41 & 93.11 & 98.73 & 15.22 \\
\hline 2016_6 & 16.13 & 1.33 & 44.28 & 346.33 & 46.37 & 34.27 & 15.84 \\
\hline 2016_7 & 67.46 & 2.18 & 37.41 & 830.47 & 356.69 & 267.88 & 15.04 \\
\hline 2016_8 & 7.81 & 1.39 & 25.90 & 194.96 & 43.44 & 32.68 & 8.76 \\
\hline 2016_EU average & 18.35 & 1.52 & 34.33 & 342.42 & 72.03 & 54.83 & 11.89 \\
\hline
\end{tabular}

AWU - annual work unit, full-time person equivalent.

Grey colour - values of variables above the European average.

Source: Own work based on FADN 2018. 
Using the Gretl Program, forward stepwise variable selection is introduced. As a result, the RE and FE Models are obtained. Results of the estimation of its parameters are presented in Table 4.

In the obtained models, five variables have positive and statistically significant influence on dependent variable, namely: labour input, agricultural area, current assets, livestock output, liabilities, net investment and cash flow. This means that the higher the values of these variables, the higher the value of family farm net income. The highest positive influence on a dependent variable is exerted by cash flow. Family farm net income is also negatively impacted by variable inputs. Overall correctness of classification is high (above 40\%). The values of VIF test for all variables are below 10.0 (Tab. 4).

Table 4. Panel models for family farm income according to the type of production TF8

\begin{tabular}{|c|c|c|c|c|c|c|c|c|}
\hline \multirow{2}{*}{ Details } & \multicolumn{8}{|c|}{ Type of production } \\
\hline & 1 & 2 & 3 & 4 & 5 & 6 & 7 & 8 \\
\hline Hausman Test & $\begin{array}{c}\chi^{2}(4)= \\
12.70 \\
(0.0128)\end{array}$ & $\begin{array}{c}\chi^{2}(3)= \\
10.00 \\
(0.0185)\end{array}$ & $\begin{array}{c}\chi^{2}(4)= \\
8.76 \\
(0.0673)\end{array}$ & $\begin{array}{c}\chi^{2}(3)= \\
9.15 \\
(0.0274)\end{array}$ & $\begin{array}{c}\chi^{2}(4)= \\
17.26 \\
(0.0017)\end{array}$ & $\begin{array}{c}\chi^{2}(4)= \\
17.19 \\
(0.0018)\end{array}$ & $\begin{array}{c}\chi^{2}(3)= \\
23.28 \\
(0.3508)\end{array}$ & $\begin{array}{c}\chi^{2}(3)= \\
5.25 \\
(0.1543)\end{array}$ \\
\hline Model's type & FEM & FEM & REM & FEM & FEM & FEM & REM & REM \\
\hline \begin{tabular}{|l|l|} 
(FEM:) & (REM:) \\
LSDV R
\end{tabular} & 0.8695 & 0.9789 & 0.7232 & 0.9654 & 0.7108 & 0.7184 & 0.6809 & 0.3901 \\
\hline \begin{tabular}{|l|l|} 
(FEM:) & (REM:) \\
Within R $^{2}$ & corr(y.yhat) \\
\end{tabular} & 0.7105 & 0.9393 & 0.9265 & 0.9002 & 0.3502 & 0.2915 & 0.8467 & 0.4419 \\
\hline \multicolumn{9}{|l|}{ Variables in model } \\
\hline const & $\begin{array}{r}-23.2564 \\
(0.0000)^{* * *} \\
\end{array}$ & $\begin{array}{r}-4.1678 \\
(0.0000)^{* \star \star} \\
\end{array}$ & $\begin{aligned}-1.4976 \\
(0.3182) \\
\end{aligned}$ & $\begin{array}{r}-3.2094 \\
(0.0000)^{\star \star \star *} \\
\end{array}$ & $\begin{array}{r}-7.1312 \\
(0.0815)^{\star} \\
\end{array}$ & $\begin{array}{r}-0.9738 \\
(0.5987) \\
\end{array}$ & $\begin{array}{r}-4.7272 \\
(0.1680)^{*} \\
\end{array}$ & $\begin{array}{r}-1.5805 \\
(0.6472) \\
\end{array}$ \\
\hline X01 Labour input & $\begin{array}{r}4.4578 \\
(0.0262)^{* *} \\
{[3.90]} \\
\end{array}$ & & & & & & & \\
\hline $\begin{array}{l}\text { X02 Utilised } \\
\quad \text { agricultural area }\end{array}$ & $\begin{array}{r}0.1892 \\
(0.0006)^{\star \star \star} \\
{[6.13]}\end{array}$ & & & & & & & \\
\hline X05 Current assets & & \begin{tabular}{|r|}
0.0356 \\
$(0.0000)^{\star * \star}$ \\
{$[6.90]$} \\
\end{tabular} & $\begin{array}{r}0.0231 \\
(0.0560)^{\star} \\
{[4.70]}\end{array}$ & & & & $\begin{array}{r}0.0374 \\
(0.0003)^{\star \star \star} \\
{[2.83]} \\
\end{array}$ & \\
\hline X08 Livestock output & & & & & $\begin{array}{r}0.4681 \\
(0.0000)^{* \star *} \\
{[7.62]} \\
\end{array}$ & $\begin{array}{r}0.1677 \\
(0.0010)^{* * *} \\
{[4.17]}\end{array}$ & & \\
\hline X10 Inputs & $\begin{array}{r}-0.1441 \\
(0.0000)^{* * \star} \\
{[6.66]}\end{array}$ & $\begin{array}{r}-0.0735 \\
(0.0000)^{\star \star \star} \\
{[8.86]}\end{array}$ & $\begin{array}{r}-0.1317 \\
(0.0000)^{\star \star *} \\
{[5.82]}\end{array}$ & $\begin{array}{r}-0.0818 \\
(0.0000)^{\star * *} \\
{[2.62]}\end{array}$ & $\begin{array}{r}-0.2376 \\
(0.0000)^{* * *} \\
{[5.52]}\end{array}$ & & $\begin{array}{r}-0.0562 \\
(0.0000)^{\star * \star} \\
{[2.55]}\end{array}$ & $\begin{array}{r}-0.0801 \\
(0.0000)^{\star * \star} \\
{[1.51]}\end{array}$ \\
\hline X12 Liabilities & & & & & & $\begin{array}{r}0.0488 \\
(0.0017)^{\star * \star} \\
{[1.84]}\end{array}$ & & \\
\hline X15 Net investment & & & $\begin{array}{r}0.1358 \\
(0.0139)^{\star \star} \\
{[1.12]} \\
\end{array}$ & $\begin{array}{r}0.0577 \\
(0.0186)^{\star *} \\
{[1.11]} \\
\end{array}$ & $\begin{array}{r}0.3135 \\
(0.0000)^{\star * \star} \\
{[1.32]} \\
\end{array}$ & $\begin{array}{r}0.2200 \\
(0.0000)^{\star * \star} \\
{[1.08]}\end{array}$ & & \begin{tabular}{|r|}
0.2846 \\
$(0.0000)^{\star * \star}$ \\
{$[1.02]$} \\
\end{tabular} \\
\hline X16 Cash flow & $\begin{array}{r}0.9756 \\
(0.0000)^{\star \star \star} \\
{[3.14]} \\
\end{array}$ & $\begin{array}{r}0.9448 \\
(0.0000)^{* * *} \\
{[3.37]} \\
\end{array}$ & $\begin{array}{r}0.9189 \\
(0.0000)^{\star * *} \\
{[3.90]}\end{array}$ & $\begin{array}{r}0.9370 \\
(0.0000)^{\star * \star} \\
{[2.59]}\end{array}$ & $\begin{array}{r}0.2809 \\
(0.0002)^{\star * *} \\
{[1.96]}\end{array}$ & $\begin{array}{r}0.2257 \\
(0.0001)^{\star * \star} \\
{[2.97]}\end{array}$ & $\begin{array}{r}0.8224 \\
(0.0000)^{\star \star *} \\
{[1.39]}\end{array}$ & $\begin{array}{r}0.8259 \\
(0.0000)^{\star \star *} \\
{[1.50]}\end{array}$ \\
\hline
\end{tabular}

The levels of significance in round brackets.

The value of VIF test in square brackets.

Source: Own calculations. 
The influence of independent variables on a family farm income is diversified according to the type of production. For example, in the fieldcrops farms the labour input and agricultural area are very important, while in the milk farms the livestock production and net investment are significant. In both types the impact of cash flow is positive, and the influence of inputs is negative (Tab. 4). Therefore, obtained results allow to confirm the first hypothesis of research, according to which determinants affecting income vary depending on the type of production of the farm.

The different influence of labour, area and capital on income is also supported by panel models ${ }^{8}$. Using the Gretl Program, forward stepwise variable selection is introduced and the RE and FE Models are obtained (Tab. 5).

Table 5. Panel models for family farm income and production factors according to the type of production TF8

\begin{tabular}{|c|c|c|c|c|c|c|c|c|}
\hline \multirow{2}{*}{ Details } & \multicolumn{8}{|c|}{ Type of production } \\
\hline & 1 & 2 & 3 & 4 & 5 & 6 & 7 & 8 \\
\hline Hausman Test & $\begin{array}{c}\chi^{2}(3)= \\
2.81 \\
(0.4222)\end{array}$ & $\begin{array}{c}\chi^{2}(3)= \\
6.76 \\
(0.0799)\end{array}$ & $\begin{array}{c}\chi^{2}(3)= \\
7.90 \\
(0.0481)\end{array}$ & $\begin{array}{c}\chi^{2}(3)= \\
7.42 \\
(0.0595)\end{array}$ & $\begin{array}{c}\chi^{2}(3)= \\
2.61 \\
(0.4559)\end{array}$ & $\begin{array}{c}\chi^{2}(3)= \\
7.14 \\
(0.0674)\end{array}$ & $\begin{array}{c}\chi^{2}(3)= \\
8.40 \\
(0.0384)\end{array}$ & $\begin{array}{c}\chi^{2}(3)= \\
14.92 \\
(0.0019)\end{array}$ \\
\hline Model's type & REM & REM & FEM & REM & REM & REM & FEM & FEM \\
\hline \begin{tabular}{l|l|} 
(FEM:) & (REM:) \\
LSDV R² & theta \\
\end{tabular} & 0.7585 & 0.7907 & 0.8740 & 0.7725 & 0.7713 & 0.8351 & 0.6255 & 0.4569 \\
\hline \begin{tabular}{l|l} 
(FEM:) & (REM:) \\
Within $R^{2}$ & corr(y.yhat) \\
\end{tabular} & 0.2755 & 0.4348 & 0.1640 & 0.2958 & 0.2956 & 0.0163 & 0.1349 & 0.2044 \\
\hline \multicolumn{9}{|l|}{ Variables in model } \\
\hline const & $\begin{array}{r}14.0902 \\
(0.0038)^{\star \star \star}\end{array}$ & $\begin{array}{r}-7.8131 \\
(0.1918) \\
\end{array}$ & $\begin{array}{r}5.2042 \\
(0.1679) \\
\end{array}$ & $\begin{array}{r}2.6288 \\
(0.5840) \\
\end{array}$ & $\begin{array}{r}35.3230 \\
(0.0000)^{\star \star \star} \\
\end{array}$ & $\begin{array}{r}14.8374 \\
(0.0000)^{\star * *} \\
\end{array}$ & $\begin{array}{r}9.4933 \\
(0.0909)^{*}\end{array}$ & $\begin{array}{r}52.7414 \\
(0.0000)^{\star \star \star} \\
\end{array}$ \\
\hline X01 Labour input & $\begin{array}{r}-2.6957 \\
(0.2799) \\
{[3.90]} \\
\end{array}$ & $\begin{array}{r}7.4460 \\
(0.0000)^{\star \star \star} \\
{[2.57]} \\
\end{array}$ & $\begin{array}{r}-1.3553 \\
(0.2984) \\
{[1.53]} \\
\end{array}$ & $\begin{array}{r}2.3826 \\
(0.1464) \\
{[1.62]} \\
\end{array}$ & $\begin{array}{r}-7.3454 \\
(0.0000)^{\star \star \star} \\
{[21.37]}\end{array}$ & $\begin{array}{r}-2.1826 \\
(0.1160) \\
{[6.75]} \\
\end{array}$ & $\begin{array}{r}-1.1557 \\
(0.3735) \\
{[1.12]} \\
\end{array}$ & $\begin{array}{r}-5.6689 \\
(0.0000)^{\star \star *} \\
{[12.78]}\end{array}$ \\
\hline $\begin{array}{l}\text { X02 Utilised } \\
\quad \text { agricultural area }\end{array}$ & $\begin{array}{r}0.0918 \\
(0.0797)^{*} \\
{[4.12]}\end{array}$ & $\begin{array}{r}0.3170 \\
(0.0270)^{\star \star} \\
{[1.33]}\end{array}$ & $\begin{array}{r}0.4426 \\
(0.0349)^{\star *} \\
{[1.54]}\end{array}$ & $\begin{array}{r}0.0916 \\
(0.6439) \\
{[1.70]} \\
\end{array}$ & $\begin{array}{r}0.0988 \\
(0.0996)^{*} \\
{[22.64]}\end{array}$ & $\begin{array}{r}0.0063 \\
(0.8619) \\
{[7.53]} \\
\end{array}$ & $\begin{array}{r}0.8230 \\
(0.0000)^{\star * *} \\
{[2.16]}\end{array}$ & $\begin{array}{r}-0.3989 \\
(0.0000)^{\star * *} \\
{[14.09]}\end{array}$ \\
\hline X03 Total assets & $\begin{array}{r}0.0110 \\
(0.0001)^{\star * *} \\
{[1.22]}\end{array}$ & $\begin{array}{r}0.0320 \\
(0.0001)^{\star * \star} \\
{[2.24]}\end{array}$ & $\begin{array}{r}0.0461 \\
(0.0000)^{\star * *} \\
{[1.11]}\end{array}$ & $\begin{array}{r}0.0216 \\
(0.0000)^{\star * \star} \\
{[1.65]}\end{array}$ & $\begin{array}{r}0.0113 \\
(0.0092)^{\star * \star} \\
1.29 \\
\end{array}$ & $\begin{array}{r}0.0106 \\
(0.0100)^{* *} \\
{[1.36]}\end{array}$ & $\begin{array}{r}-0.0015 \\
(0.8203) \\
{[2.02]}\end{array}$ & $\begin{array}{r}0.0374 \\
(0.0000)^{\star * *} \\
{[1.55]}\end{array}$ \\
\hline
\end{tabular}

The levels of significance in round brackets.

The value of VIF test in square brackets.

Grey colour - level of significance below 0.0500 .

The crossed out fields - VIF test above 10.0 (collinearity).

Source: Own calculations.

In the obtained models, family farm net income is mostly impacted by variable total assets (in 7 types out of 8 ). The remarkable differences among the types of production are observed. For example, in horticulture farms the combination of labour, land and assets are very important, but in granivores farm only land is considerable. Also, in crop

8 The labour was represented by X01 - labour input [in AWU], the land was represented by X02 - utilised agicultural area [in hectares], the capital was displayed by $\mathrm{X} 03$ - total value of assets, that is balance sheet total [in thousands EUR]. 
types of production, the agricultural area is identified as important factor that stimulates farm incomes (Tab. 5). Therefore, obtained results allow to confirm the second hypothesis of research, according to which classic production factors (work, land, capital) are used differently in different type of production.

\section{Conclusions}

Family farm income is a remuneration payable to farmers for the use of work, land and capital of the farm and in order to cover risks of agricultural activity. The farm income stability has been one of the goals of agricultural policy in the EU.

Using panel models, the paper presents the family farm incomes and their determinants, such as: labour input, agricultural area, assets, livestock output, liabilities, inputs, net investment and cash flow. The hypothesis of research, according to which determinants affecting income vary depending on the type of production of the farm, is confirmed. However, one can observe that incomes in all types of farms are highly dependent on the value of the cash flow.

The importance of labour, land and capital is not equal in different types of production. Particularly, in crop types of production, the agricultural area and total assets are identified as the important factor that stimulates farm incomes. Meanwhile, in livestock types of production, the assets are the most important determinant of income. So, the hypothesis according to which significance of work, land, and capital is different in each type of production can be sustained.

The main limitation of undertaken research stems from the use of average values of variables from FADN database. In order to overcome it the future research could encompass data from individual farms obtained from appropriate surveys.

\section{References}

ADKINS, L. C. (2014): Using gretl for Principles of Econometrics, 4th Edition Version 1.041, April 7, Oklahoma State University, Oklahoma, s.133, 253-254.

ARBIA, G., PIRAS, G. (2005). Convergence in per-capita GDP across European regions using panel data models extended to spatial autocorrelation effects. Istituto di Studi e Analisi Economica, Working Paper. No. 51, May, s.16.

ASAI, M., MORAINE, M., RYSCHAWY, J., DE WIT, J., HOSHIDE, A. K., MARTIN G. (2018). Critical factors for crop-livestock integration beyond the farm level: A crossanalysis of worldwide case studies. Land Use Policy. 2018, No. 73(2018), s. 184-194.

BALTAGI, B. H. (2005) Econometric Analysis of Panel Data. 3rd Edition, John Wiley \& Sons Ltd., Chichester, s. 6, 12-18.

BECK, A. C., DENT, J. B. (1987) A Farm Growth Model for Policy Analysis in an Extensive Pastoral Production System. Australian Journal of Agricultural Economics. 1987, Vol. 31, No. 1 (April), s. 2944. 
BERBEL, J., RODRIGUEZ-OCAÑA, A. (1998) An MCDM approach to production analysis: An application to irrigated farms in Southern Spain. European Journal of Operational Research. 1998, No 107, s. 108-118.

CARY, J. W., HOLMES, W. E. (1982) Relationships among farmers' goals and farm adjustment strategies: some empirics of a multidimensional approach. Australian Journal of Agricultural Economics. 1982, Vol. 26, No 02, August, s. 114-130.

Comparison of farmers' incomes in the EU Member States (2015). European Parliament, DirectorateGeneral For Internal Policies Policy Department B: Structural And Cohesion Policies, Agriculture and Rural Development, June 2015, IP/B/AGRI/IC/2014-68, PE 540.374, s. 12.

Enabling smallholder farmers to improve their incomes (2017). White Paper "Improving Incomes Challenge" by Sustainable Food Lab and Business Fights Poverty. September 2017, s. 2.

ERGÜN, U., GÖKSU, A. (2013): Applied Econometrics with Eviews Applications, International Burch University, Sarajevo, s. 113.

EUROPEAN COMMISSION (2014a) Definitions of Variables used in FADN standard results. Brussels, December 2014. RI/CC 882 Rev.9.2 (EN), s. 5.

EUROPEAN COMMISSION (2014b) EU Farm Accountancy Data Network. 50 years of support for EU agriculture and farmers. Retrived: http://ec.europa.eu/agriculture/rica/pdf/FADN-EN-2014.pdf. Access: 22.06.2018.

EUROSTAT (2016) Agriculture statistics - family farming in the EU. Retrived: http://ec.europa.eu/eurostat/statistics-explained/index.php?title=Agriculture_ statistics_-_family _ _ farming_in_the_EU\&oldid=352405. Access: 06.06.2018.

FADN (2018) Retrieved: http://ec.europa.eu/agriculture/rica. Access: 20.06.2018.

FAO (2014) Retrieved: http://www.fao.org/family-farming-2014/home/what-is-family-farming/en/. Access: 20.06.2018.

FRAWLEY, J. P., COMMINS, P., SCOTT S., TRACE F. (2000) Low Income Farm Households: Incidence, Characteristics, and Policies. Combat Poverty Agency and Oak Tree Press, Dublin, s. 17.

GASSON, R. (1973) Goals and values of farmers. Journal of Agricultural Economics. 1973, No. 24, s. 521 524.

GRETL PROGRAM. Retrived: http://www.kufel.torun.pl. Access: 06.06.2018.

IBRAHIM, H. Y., OMOTESHO, O. A. (2011) Optimal farm plan for vegetable production under Fadama in North Central Nigeria, Trakia Journal of Sciences. 2011, Vol. 9, No. 4, s. 43-49.

IFAD (2010) Integrated crop-livestock farming systems. International Fund for Agricultural Development, Rome, Livestock Thematic Papers, February, s. 1.

LOWDER, S. K., SKOET, J., RANEY, T. (2016) The Number, Size, and Distribution of Farms, Smallholder Farms, and Family Farms Worldwide. World Development. 2016, Vol. 87, s. 16-29.

MADDALA, G. S. (1987) Limited Dependent Variable Models Using Panel Data. The Journal of Human Resources. 1987, Vol. 22, No. 3 (Summer), s. 307-338.

NIBBERING, J. W., VAN RHEENENH, T. (1998) The Development of a Quantitative Method for Setting Research Priorities: A Critical Assessment. Agricultural Systems. 1998, Vol. 56, No 2, s. 145-165.

OECD (2003) Farm Household Income. Issues and Policy Responses. OECD Publications, Paris, s. 12. 
OKORUWA, V., JABBAR, M. A., AKINWUMI, J. A. (1996) Crop-livestock competition in the West African derived savanna: Application of a multi-objective programming model. Agricultural Systems. 1996, No. 52 , s. 439-453.

ROSATO, P., STELLIN, G. (1995) Multi criteria analysis in farm management following the common agricultural policy reform: an application of multi-objective integer linear programming. Fourth Minnesota Padova Conference on Food, Agriculture, and the Environment, April (Working Paper WP95-3), Paper 4.

SEVERINI, S., TANTARI, A. , DI TOMMASO, G. (2016) The instability of farm income. Empirical evidences on aggregation bias and heterogeneity among farm groups. Bio-based and Applied Economics. 2016, No. 5(1), s. 63-81.

SOLANO, C., LEÓN H., PÉREZ, E., HERRERO, M. (2001) Characterising objective profiles of Costa Rican dairy farmers, Agricultural Systems. 2001, No. 67, s. 153-179.

The Future of Food and Farming (2017) European Commission COM(2017) 713 final. 29 November 2017, Brussels, s. 14.

WALLACE, M. T., MOSS, J. E. (2002) Farmer Decision-Making with Conflicting Goals: A Recursive Strategic Programming Analysis. Journal of Agricultural Economics. 2002, Vol. 53, No 1, March, s. 82-100.

WOOLDRIDGE, J. M. (2013) Introductory Econometrics. A Modern Approach. 5th Edition, South-Western Cengage Learning, Mason, s. 10, 496. 